\title{
A GRADUATED SCALE FOR DETERMINING MENTAL AGE
}

C. B. CORNELL, PH. D.

ACTING HEAD OF THE DEPARTMENT OF PSYCHOLOGY UNIVERSITY OF KENTUCKY, LEXINGTON

$966 L$ 8عE IZO 0

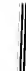

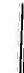



"A Graduated Scale for Determining Mental Age"

BY

\section{Clare Brown Cornell}

\section{A Thesis}

Presented to the Faculty of The Graduate College in the University of Nebraska in Partial Fulfillment of Requirements for the Degree of Doctor of Philosophy 


\section{Publisbers}

STATE JOURNAL CO.

Frankfort, Ky.

\section{Copyright 1918 by}

Clare Brown Cornell

$$
\begin{aligned}
& \text { A. } \\
& \text { Dec it }\left.12\right|^{2}
\end{aligned}
$$




\section{Acknowledgments.}

In working out a problem which has as its basic material the measuring of human intelligence one is quickly brought to feel his absolute tependence on his fellows. In art, in the other fields of science, in literature, given a well equipped laboratory, or a shelf of carefully selected broks and periodicals, the task of working out an investigation beconres one of cataloging and Hassifying known facts and of extablishing new ones. But in the field of psychology the investigator is peruliarly helpless unless he ean secur" the intelligent "o-operation of people who see the value of his wotk. The author of this monograph was especially fortunate in this respert. and wishes to take this opportunity of expressing his appreciation of the assistance given him by the teaching force of the Lincoln (Nehr.) Publie Sohools. Thanks are particularly due to superintentent Fred M. Hunter, who gave him the freedom of the entire system: and to the prin-ijuls of the eight schools from which the whildren were selerted. namely, E. Ruth I'yrtle, pritcipal of Mrhinley School, Lena IIerrill, prineipal of Saratoge school, Emma Morrill, principal of Everett Sehool, Mattie Allen, principal of Whittier School, J. Belle Corbin, prineipal of Bancroft School, Clare Mc.Phee, prineipal of Capitol sichool, Bertha $K$. (ireen, prineipal of clinton school, and sarlie Baird, princepal of Elliott School.

The anthor is greatly indebted to I)r. II, K. Wolfe, head of the Bepartment of Prychology in the Cniversity of Nebraska, who suggested and directed the investigation, and to Dr. Win:fred Hyde for helpful critirisms during the process of arranging the material.

Lineoln, Nebr., July ?0. 1915.

The Author.

After carefully checking the data and after using the seale in a large number of cases covering a period of three years, the author feels justified in presenting the work in its complete form. The results obtained by the use of the seale are aceurate to a marked degree. Correlation of the individual tests with results obtained by the Binet scale are deeidedly close.

Lexington, Ky... July 10, 1918.

C. B. C. 



\title{
A Graduated Scale For Determining Mental Age.
}

\author{
Introduction.
}

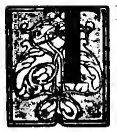

HE science of mental measurement is a logical outgrowth of experimental psychology and can be traced indirectly to Fechner and Wundt. Although based upon seemingly intangible psychie phenomena, its methods nevertheless parallel those of the other sciences. There is this difference, however, between the two fields: in the other sciences definite units of measurement have been established and generally accepted, whereas in the science of mental measurement, very few standard units have as yet been fully developed, owing to the peculiar difficulties inherent in any attempt to determine the required norms. "The problem for quantitative study of the mental sciences is to devise means of measuring things, differences, changes and relationships for which standard units of amount are often not at hand, which are variable, and so unexpressible in any case by a single figure, and which are so complex, that to represent any one of them a long statement in terms of different sorts of quantities is eommonly needed." $(25,6)$ But in spite of the difficulties encountered a relative degree of success has attended the search for units whereby mental abilities can be relatively measured.

Methods of procedure have been evolved by Fechner, ${ }^{(9)}$ Wundt, ${ }^{(32)}$ Ebbinghaus, ${ }^{(7)}$ Muller, ${ }^{(17)}$ and others, but the application to pedagogical problems has been a comparatively recent development. Undoubtedly the greatest stimulus toward this came from Binet in France, whose work was quickly taken up in Germany and in this country. The various modifications and elaborations of Binet's tests have filled the field with a rich literature.

The eurrent interest in mental tests is undoubtedly largely due to the need felt, on the part of teachers and supervisors, for an efficient instrument wherewith correctly to diagnose and classify school children. This attitude is wholly in keeping with the recent trend of our public school system which is more and more readjusting itself to the problem of meeting the needs of the individual child.

The following investigation is the result of an attempt by the anthor to find a satisfactory scale for mental measurement 
to be used in the public sehools. In easting about for standardized tests none was found which combined the age scale with the essentials of diagnosis.

The novice in the work is at once attracted by the Binetsimon scale, but it is to be doubted if the results obtained in its application can be considered reliable. A careful analysis of the scale, from the standpoint of the psycho-elinicist, reveals many defeets which camnot be explained away. The seale falls far short of being the magical instrument which its many exponents claim it to be and will never serve as an instrument of exaet analysis. However, a criticism of the Binet seale is beyond the scope of the present work, especially in the light of the literature of the subjeet. Its relative success in clinical work would seem to result form the fact that, throughout the seale. there exists a psychological framework which insures approximate results despite a large amount of extraneous material.

The greatest obstarle entountered in the practical applitation of any method is the laek of coherence and system. In the measuring of mental processes the tests must necessarily cover a wide range in order to determine the true ability of the subject. Tests which ascertain ability in one phase must be supplemented by tests applicable to other operations of the mind. Take. for example the Ebhinghaus " Combinationsmethode," familiarly known as the completion method. $(8,401),(29,283)$ In this test a story is given to the child with syllables or entire words omitted from the text. The problem is for the ehild to fill in the blank spares in an intelligent manner in the least possible time. The author claims that this is a "real test of intelligence, a simple. easily applied device for testing those intellectual activities that are fundamentally important and signifieant both in the sclool and in life." Artual application, however, shows that the test is not as comprehensive as the author claims, is difficult to evaluate, ${ }^{(24)}$ and is dependent on school training. ${ }^{(30)}$ But, in spite of these objections, it may be used as one of a group owing to its close correlation with intelligence. ${ }^{(6,126)}$

The seale proposed in the present monograph is an attempt to combine the determination of mental age with psychological diagnosis. It is composed of nine separate tests. divided into three general group, as follows:

A. Perception, tests $I$, and $1 X$.

B. Memory,

(a) Auditory, tests II, and III.

(b) Visual. test IV.

(c) Logical. test $\mathrm{V}$.

C. Judgment.

(a) Visual proportion, test VI.

(b) Constructive problems, test VII.

(c) Definitions, test VIII.

The characteristic features of the scale are as follows: (1) The same tests are used for all ages and the mental age determined by the manner of the individual reaction, measured in

*For criticisms of the Binet scale see especially references 7, 22, $23,24,27$ and 35 . 
terms of the relative number of points for each age. (Norms have been established for the ages six to fourteen, inclusive.) This method dispenses with a great amount of unnecessary labor, both on the part of the experimenter and of the child, because of the fact that standing is measured in terms of ability to react. (2) The tests chosen are necessarily of such a nature as to appeal to the interest of the ehild regardless of age. Moreover, as a proof that they are genetic tests of intelligence, the ability to react to each test increases uniformly as we go up the age scale, with a fairly wide range between the upper and lower limits. (3) The tests measure native ability regardless of training. This feature opens up a wide field for discussion. For example, Binet uses as tests, counting, knowledge of money, family name, dates, and others which may be influenced by training. One of $\mathrm{my}$ tests is for the child to name all the objects that he can think of during one minute, with the eyes closed. This may be open to criticism of training, but the evidence shows that the more intelligent the child, the greater the number of associations, even though the type of words suggest the influence of previous training or environment. (4) The tests are comprehensive, that is, they are so arranged that the several basie mental operations may be analyzed. (5) They are compact and systematic. The apparatus, aside from the stop-watch, can be made in the school room or office, and, with the exception of the eard of objects, may be carried in a large envelope. The number of tests is small but each is important. (6) The tests may be easily and quickly applied. It is believed that any teacher who understands the principles of psychological method can, after perhaps fifty trials, conduct the test in about thirty minutes, with comparatively accurate results. (7) The results may be accurately evaluated, provided the data are correct. This is made possible by the systematic scoring by means of points. ${ }^{*}$ (8) The results are significant from the standpoint of the clinical psychologist, indicating to the trained observer the type of the subject.

It is believed that the scale is a simple and coherent system which may be efficiently used, both to determine mental age and mental type. In the hands of the novice it will indicate not only the group to which the child belongs, but also his predominating characteristies. The expert will find it valuable as an index to further tests which may be deemed necessary for a more complete analysis of the subject's mentality. In any case, with careful manipulation. the mental age will be closely determined.

\section{Source of the Data.}

In establishing the norms presented in this work the tests were given personally by the author to about 550 children of the Lincoln Public Schools. Of this number, 75 were tested before the method was fully worked out, about 75 more were tested

* The entire plan of the work was completed and the data more than half collected before the method of the point scale used by Yerkes and Bridges (34) was available. Reference to thelr scale will show the radically different methods between the two systems. 
during the year for elinical purposes, leaving 404 in the group from which the suale was ultimately established, or an average of 45 for each of the nine ages. These children were taken from eight different schools, collectively representative of all classes of population usually found in a cosmopolitan eity. McKinley School is located in the heart of the business section with a decidedly eosmopolitan community furnishing the students, with a predominance of foreign shopkeepers and peddlers. Saratoga School, in the south part of the city, has grown up within five years to accommodate the children of a multitude of small home owners. Everett School is one of the oldest in the system, with a very stable student population, in a fairly well-to-do community. Whittier School is located on the north side in a much poorer section of the city than those previously mentioned, with a large German element and many mechanies. Bancroft has the same class of children in attendance as Whittier. In both of these schools the absence of fourteen-year-olds in the upper grades was noticeable. Capitol School is located in the oldest residence section with many children of comparatively rich parents in attendance. Clinton School is an opposite extreme, being located in an outlying district of cheaper homes and rented houses. The last school visited, Elliott, is located in an average residence section and has a stable attendance.

The children were selected by the principal in conjunction with the teacher, after the problem had been carefully explained by the experimenter. Teachers and principals, as well as the children, were intensely interested in the work and put forth every effort to contribute to its success. It was required of each rhild that he be "just average or normal," neither accelerated nor retarded, that is, that the pedagogical age should corrsepond with the chronological age. The child's physical development and condition at the time of taking the test were carefully considered. A great deal of confidence is placed in the type of children selected because of the fact that each principal has known practically each child from the time of entrance, in most eases being entirely familiar with the child's family history. Furthermore the work was undertaken at an opportune time because of the fact that the Principals' Club was working on the problem of classification, and the principals were particularly interested in the method of procedure.

The collection of data was begun in November, 1914, and was continued until the middle of June, 1915.

The children of each age group were within the limits of five montlis over and four months under the year; for example, the seven year group ranged from six years and eight months to seven years and five months, with an average fairly close to the year. An effort was made to keep the mean variation of age as low as possible. 
TABLE I.

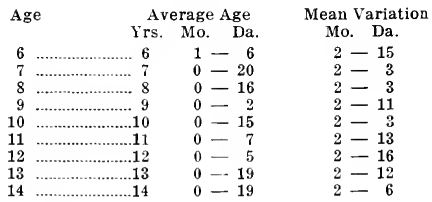

Method of Conducting Tests.

The method employed in eonducting the tests is similar to that used in the Binet tests and their modifications. A room was provided in each building which would be as quiet and free from disturbance as possible. In a few cases where it was necessary to use the principal's office the tests were suspended during the transacion of rontine business. In each school the experimenter was given every possible eonsideration which contributed not a little toward the suecessful manipulation of the tests. A small table was placed opposite the windows with the experimenter seated facing the light and with the ehild on his right. From the moment the child entered the room he was treated with cordial respect and made to feel perfectly at ease, with the understanding that he was contributing toward the solution of the problem rather than merely being tested. In some eases the problem was explained in some detail, while in others the child was merely informed that his help was desired in finding out the ditierence between the upper and lower grades. In no case was the test begun until ihe child felt at home and was in the attitude which would produce uniform results. In the great majority of cases the children entered the room with an evident feeling of pleasant anticipation and euriosity dne. perhaps, to the advertising which the tests had received at the hands of those previously taking them. Each child was eautioned not to tell anything about the tests and no evidence was discovered which would indicate that they had been talked over among the children. As a matter of fact the nature of the tests is such that previous information or coaching would have but little effect on the final results. The tests were all given during the regular school hours and averaged thirty minutes for each child. All data was reeorded on the aecompanying blank. Drawings made by the child were kept on a separate sheet of blank paper which was later attached to the blank. The recording was done $h y$ the experimenter and no effort was made to conceal this fact from the subject. 
TEST BLANK

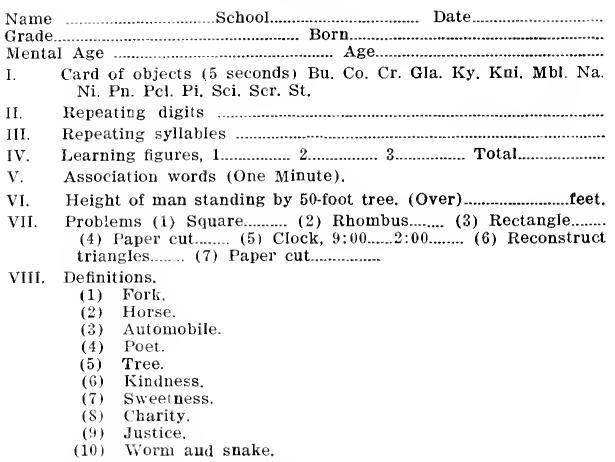
IX. Sorting cards. $\min$ $\sec$ piles

Equivalent value min... sec.

\section{Test I.}

In this test fifteen objects, familiar to all children, are fastened on a white card board $37 \mathrm{~cm}$. square, and covered with another card board of the same dimensions (See Fig. 1.) The ol,jects are in desiription and size as follows: One black button $29 \mathrm{~mm}$. in diameter; an aluminum comb $130 \mathrm{~mm}$. long; a green erayon of standard form and size; a pair of blue glasses; a flat Yale key; a pearl-handled penknife $60 \mathrm{~mm}$. long; a blue marble $14 \mathrm{~mm}$. in diameter; an eight-penny nail; a Buffalo nickel; a gold pen point; a red paper pencil $80 \mathrm{~mm}$. long; a red clay soap-bublle pipe; a small pair of seissors; an ordinary serew $60 \mathrm{~mm}$. long; and a five-cent postage stamp.

In giving the test the covered card is placed in front of the child and used as a stimulus for close attention with the explanation: "I have a lot of things fastened on this card; now I'm going to show them to you for just a few seconds and then when I cover them up you tell me what you saw. Now, look closely, ready-." The objects are exposed for five seconds and must he covered quickly but quietly. Any undue disturbance on the part of the observer is sufficient in some cases to interfere materially with the reaction. Incidentally, it is necessary to keep the child's interest and attention focussed on the work from beginning to end of the series. This is usually accomplished by presenting the tests in succession without pause.

The results are summarized in table II. 


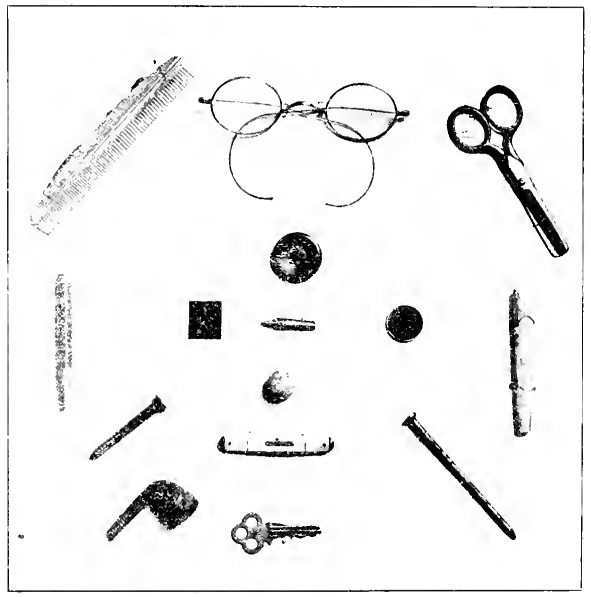

TABLE II.

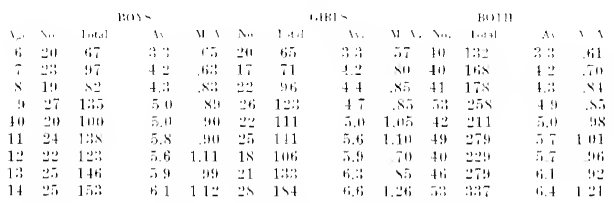

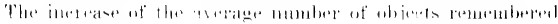

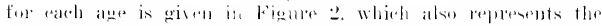

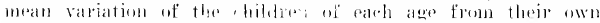

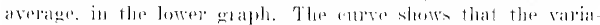

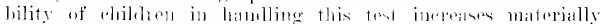

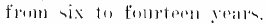

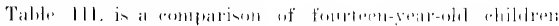

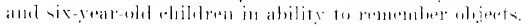




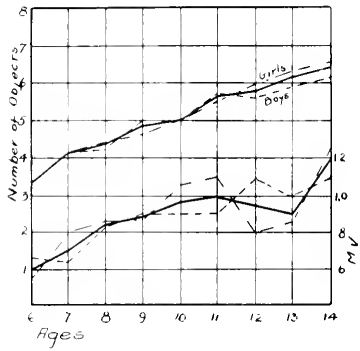

TABLE III.

\begin{tabular}{|c|c|c|c|}
\hline & ti lros & $1+$ Irs & $\therefore$ Intretesto \\
\hline $1001=$ & $:::$ & ii. 1 & $\mathrm{si}$ \\
\hline (i) & $\because \therefore$ & iiti & 1101 \\
\hline $1: 0+1 \mathrm{n}$ & $: ;: 3$ & ti 4 & $4 t$ \\
\hline
\end{tabular}

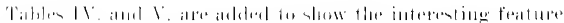

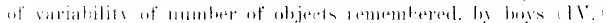
alul enlis, 1 .

\section{TABLE IV.}

\section{Boys.}

\begin{tabular}{|c|c|c|c|c|c|c|c|c|c|c|c|c|c|c|}
\hline 1... & $\checkmark$ & $1 \leqslant 1$ & f.. & 1. & 1.1 & $1 .$. & $\mathrm{k} \cdots$ & W. & 1. & $x_{1}$ & $1: \ldots$ & 11.1 & 1. & \\
\hline i: & $\therefore 1$ & 1 & 5 & 5 & $\checkmark$ & 1 & $i$ & $\overline{7}$ & 1 & 1 & 11 & $::$ & 1 & \\
\hline 7 & $\because: 3$ & 1 & 11 & $i$ & $1: 3$ & ? & 12 & s & 1 & 1 & $\because$ & 12 & 1 & \\
\hline s & $1 ! 1$ & 1 & 7 & i & & $\therefore$ & (11) & $\therefore$ & : & $: \because$ & 1 & 7 & 1 & \\
\hline$\because$ & 27 & 2 & $1^{\prime \prime}$ & $!$ & 201 & 11 & 14 & $!$ & 5 & $x$ & $\therefore$ & 7 & 1 & \\
\hline 111 & $\therefore 11$ & 1 & 11 & 12 & 14 & ti & 11 & $t$ & 1 & 9 & 4 & $\mathrm{x}$ & & \\
\hline 11 & $2 t$ & $\therefore$ & 12 & $1: 3$ & 17 & 4 & 15 & 10 & ti & 111 & $\ddot{\prime}$ & 10 & $1:$ & \\
\hline 12 & 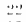 & : & ! & 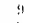 & 13 & 4 & 12 & 5 & 2 & 11 & 1 & 11 & 1 & \\
\hline 13 & 25 & $: 3$ & 15 & $!$ & 16 & 111 & $1:$ & 9 & 9 & 1. & 4 & 10 & 1 & \\
\hline 14 & ב. & $\therefore$ & 15 & 12 & 17 & s & 15 & $1 i$ & is & 14 & 8 & 11 & 1 & \\
\hline
\end{tabular}

TABLE V.

Girls

\begin{tabular}{|c|c|c|c|c|c|c|c|c|c|c|c|c|c|c|c|}
\hline $1 .$. & $\checkmark$ & $P=-$ & (... & 1. & (.) & k. & $k \cdots$ & WI. & W & 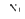 & I" & $1: 1$ & Iי & $\therefore$ & 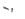 \\
\hline$t_{i}$ & $\because 11$ & 1 & $\because$ & $\because$ & 14 & $\because$ & $\overline{7}$ & 8 & $::$ & 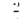 & 11 & '" & 1: & $: 2$ & 11 \\
\hline 7 & 17 & 1 & $\bar{T}$ & !t & 111 & 1 & 7 & $\bar{i}$ & : & 4 & 11 & $\overline{-}$ & if & 111 & 11 \\
\hline$s$ & $\because: 2$ & $!$ & 11 & ir & 1) & $\because$ & 4 & 4 & (j) & i & : & 10 & $!$ & 11 & $\therefore$ \\
\hline 4 & $24 i$ & $\because$ & $1: 3$ & $s$ & $1 \mathrm{~N}$ & $: 8$ & 111 & 11 & : & 10 & :" & 11 & $1 t:$ & $1:$ & 2 \\
\hline 10 & $\because 23$ & $\therefore$ & it & $1 \%$ & $1 \mathrm{~s}$ & $\bar{z}$ & 1: & 5 & ti & 4 & 5 & 12 & 11 & 14 & $\because 3$ \\
\hline 11 & 25 & 4 & 11 & $1 \mathrm{~s}$ & 20 & 5 & $1:$ & i & 1 & 4 & 6 & 10 & 10 & 16 & 1 \\
\hline 12 & 1s & 1 & 9 & 4 & 14 & 7 & b & i & $\ddot{z}$ & 6 & $\overline{7}$ & 111 & $!$ & 11 & $\ddot{\prime}$ \\
\hline $1:$ & $\because 1$ & $t$ & 11 & 1.1 & 11 & 8 & 5 & 11 & $: 3$ & 11 & 4 & 12 & 14 & 17 & 1 \\
\hline $1 t$ & $2 x$ & i; & $1 !$ & $1 t i$ & $\because 1$ & 10 & 14 & 4 & $\therefore$ & 12 & $\bar{T}$ & 15 & 17 & $1:$ & 6 \\
\hline & & 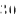 & 14 & 4 & 144 & $41:$ & 74 & $\mathrm{HiT}^{-}$ & $24 i$ & iis & $\therefore:$ & 14 & 1114 & 1117 & $\because 1$ \\
\hline
\end{tabular}


A comparison of the totals of the above tables indicates the following sex differences: The girls mention the button, crayon, glasses, pencil and seissors, a significant number of times more than do the boys; the boys mention the key, knife, nail. nickel, and serew oftener than the girls; they rank about the same in the case of the comb, marble, pen, pipe and stamp. This comparison, while somewhat irrelevant, is significant to the psychologist, and is represented graphieally in figure 3 .

Bu. Ca. Cr Gl. Ky. KniMana.Ni Pn. Pt.Pi. Sei.sr. St

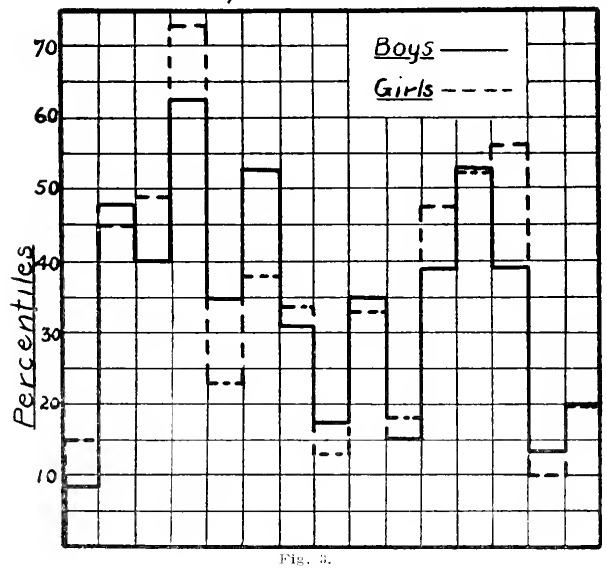

Test II.

The sormo test is one used by Binet and universally adopted hy liose who have made modifications of the BinetSimon sule. namely, anditory memory for digits. For eonvenience the child is requested to look at a designated object whieh will turn him siderise. witl the right side to the experimenter. This mothor was found more convenient than to have the child turn cumpletely around and moreover gives the experimenter an opportunity to discover whether the subject is of the motor type by watching the movement of the lips while giving the sithabies, The only explanation given is "Say these numbers after we." The following digits are then read in a smooth, even, distin.t voice, without aceent exeept for a natural lowering of the voice on the last digit of each group, which beeomes the signal for the child to hegin repeating. The rate is slightly faster than one digit per sement. 


$\begin{array}{lllllll}29 & 847 & 4297 & 52814 & 384296 & 1695847 & 41629385 \\ 81 & 315 & 5318 & 47395 & 279314 & 2964375 & 25718394 \\ 73 & 926 & 6194 & 58319 & 618492 & 9285164 & 58261947\end{array}$

The child is required to repeat correctly two out of any given group in order to receive credit for that group. In other words, he is given aredit for the number of digits in the highest group in which he is able to repeat correctly two num. bers. For example, in the fours he may repeat 4-2-9-7 correctly, fail in repeating 5-3-1-8, and then repeat 6-1-9-4 correctly, when he will proceed to the next bigher group. Then in the fives, if he should make one correct repetition, but fail in the other two, his eredit is for four digits only.

Table VI. contains the results of this test with the number of digits repeated correctly and the mean variation for each age.

TABLE VI.

Repeating Digits.

BoYs GIRLS BOTH

$\begin{array}{rrrrrrrrrrrrr}\text { Age } & \text { No. } & \text { Total } & \text { Av. } & \text { M. V. No. } & \text { Total } & \text { Av. } & \text { M. V. No. } & \text { Total } & \text { Av. } & \text { M. V. } \\ 6 & 20 & 87 & 4.3 & .54 & 20 & 90 & 4.5 & .70 & 40 & 177 & 4.4 & .64 \\ 7 & 23 & 116 & 5.0 & .52 & 17 & 82 & 49 & .60 & 40 & 198 & 4.9 & .56 \\ 8 & 19 & 102 & 5.4 & .81 & 22 & 124 & 5.6 & .78 & 53 & 226 & 5.5 & .80 \\ 9 & 27 & 154 & 5.7 & .58 & 26 & 146 & 5.6 & .81 & 53 & 300 & 5.7 & .70 \\ 10 & 20 & 113 & 5.7 & .47 & 22 & 121 & 5.5 & .73 & 42 & 234 & 5.6 & .62 \\ 11 & 24 & 139 & 5.8 & .53 & 25 & 146 & 5.8 & .61 & 49 & 285 & 5.8 & .57 \\ 12 & 22 & 133 & 6.0 & .50 & 18 & 106 & 60 & .33 & 40 & 239 & 6.0 & .43 \\ 13 & 25 & 154 & 6.1 & .44 & 21 & 127 & 6.0 & .43 & 46 & 281 & 6.1 & .44 \\ 14 & 25 & 160 & 6.4 & .74 & 29 & 177 & 6.3 & .68 & 53 & 337 & 6.4 & .70\end{array}$

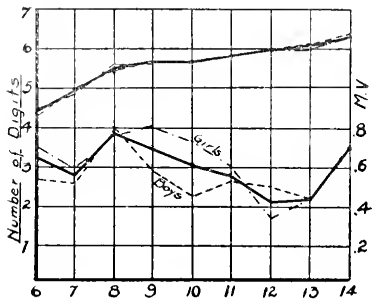

Fig. 4.

It will be noticed here that the increase is greatest from six to eight, with a slight drop at ten, and a constant increase from ten to fourteen. The per cent. of increase in toto from six to fourteen is given in table VII. The increase in ability to repeat digits is shown graphically in figure 4 , the lower eurve showing the variability of the mean variation, which is greatest at eight and lowest at twelve and thirteen. 
TABLE VII.

\begin{tabular}{|c|c|c|c|c|}
\hline & & 6 Yrs. & 14 Yrs. & $\begin{array}{c}\% \text { Increase. } \\
49\end{array}$ \\
\hline $\begin{array}{l}\text { Boys } \\
\text { Girls }\end{array}$ & (1) & $\begin{array}{l}4.3 \\
4.5\end{array}$ & 6.3 & 40 \\
\hline Both & .................... & 4.4 & 6.4 & 46 \\
\hline
\end{tabular}

\section{Test III.}

The third test is also taken from Binet and, like the preceding one, is a test of auditory memory. It consists in repeating syllables in sentence form, beginning with a word of two syllables, with each succeeding sentence or group of words greater than the preceding by two syllables. The sentences used are Goddard's modification of those given by Binet and Simon and are taken from Whipple's Manual. ${ }^{(28)}$

1. Papa.

2. Slipper. Letter.

3 . It is cold and snowing.

4. I have a dog. He's a fine one.

5. His name is Jack. Oh, what a naughty boy.

6. It is raining out doors, but we can stay inside.

7. We are having a fine time. We found a mouse in a trap.

8. Let`s all go for a walk today. Give me that big hat to wear.

9. Poor IIelen has just torn her new dress. She will - surely feel sorry for that.

10. Why should anyone want to do injury to such beautiful creatures as birds?

11. We expect to have a great time at the seashore, digging in the white beach sand all day long.

12. When the train crosses the road the engineer will see the wagon standing beside the apple tree.

13. My roung brother Frank had a fine time on his vacation this summer. He went fishing almost every day.

14. To start a fire in the open is one of those tricks which everyone thinks he can perform until he tries it.

15. He sinks the net in the water and waits until he can see the fish distinctly, lying perfectly still and within reach.

16. The first rapid was only the beginning; half a mile below we could see the river disappear between two points of rock.

17. One day the ehildren's grandmother came to visit them and the children were very happy because she told them beautiful fairy stories.

18. The Indians used to perform many kinds of queer, horrible dances, in the course of which they yelled and shrieked as if suffering the most painful torture.

It is necessary to pronounce the words distinctly, at a uniform rate, and without undue accent. The main objection to this test is the lack of uniform increase in difficulty from one sentence to the next. For example, I found, as did Mrs. Squire ${ }^{(22)}$ and others, that the children could often repeat the twelfth 
sentence correctly after having failed in the two or three preceding sentences. Hence, after my preliminary tests, I changed the sentence from "When the train crosses the road the engineer will blow the whistle and the fireman will ring the bell," to "When the train crosses the road the engineer will see the wagon standing beside the apple tree," a sentence less rich in assoeiative connections.

This test is given under the same conditions as the second and slould follow it without a break with the simple statement, "Repeat these words." It will be noticed that the general method of procedure in this and the preceding test differs from that given by Binet in that the child's maximum ability is found at once, that is, without interposing other tests and then reserting to the memory tests, if ability of a higher age is shown.

In order to receive credit for a sentence it is considered neiessary for the child to repeat every syllable correctly. But if a slight error oceurs in one sentenee, and the child can repeat the next correctly, he is given eredit for the latter. I made one conression in regard to verbation repetition in the eleventh sentence. Here I accepted as correct "fine time at the seashore," whereas the sentence reads "grat time at the seashore." This mistake occurred so frequently in the preliminaries in the eases of children who conld repeat the two succeeding sentenees that I felt justified in making the change.

In no ease is the child informed of his errors: when the maximum has heen rearhed we pass immediately to the next test as if there were no more sentences to be given. In this, as in all the other tests, the average child will watch for confirmation of his work. It is, of course, necessary for the experimenter to he perfectly passive. and give no sign of eommendation prior to sise completion of the work in hand.

At an early stace in the work I discovered that consideraWe time coukt he savel by hegimning with the fourth sentence for the lower ages and with the seventh or eighth for the upper ages.

\section{TABLE VIII.}

Summary of Test III. Ability to Repeat Syllables.

\begin{tabular}{|c|c|c|c|c|c|c|c|c|c|c|c|c|}
\hline \multirow[b]{2}{*}{ Ige } & \multicolumn{4}{|c|}{ oys } & \multicolumn{4}{|c|}{ GIRLS } & \multicolumn{4}{|c|}{ FО TH } \\
\hline & No. & Total & Av. & M. I. & No. & Total & Av. & M. V & $\mathrm{No}$. & Total & As. & M. I \\
\hline 6 & 20 & 310 & 15.5 & 1.4 & 20 & 318 & 15.9 & .77 & 40 & 628 & 15.7 & 1.08 \\
\hline 7 & 23 & 374 & 16.3 & 1.1 & 17 & 268 & 15.8 & 1.08 & 40 & 642 & 16.0 & 1.09 \\
\hline 8 & 19 & 322 & 16.9 & 1.5 & 22 & 378 & 17.2 & 1.55 & 41 & 700 & 17.1 & 1.53 \\
\hline 9 & 27 & 492 & 18.2 & 1,75 & 26 & 470 & 18.0 & 1.46 & 53 & 962 & 18.1 & 1.60 \\
\hline 10 & 20 & 354 & 17.7 & $1.7 \%$ & 22 & 404 & 18.4 & 1.75 & 42 & $75 \mathrm{~s}$ & 18.0 & 1.74 \\
\hline 11 & 24 & 492 & 20.5 & 2.25 & 25 & 471 & 18.8 & 1.76 & 49 & 963 & 19.7 & 2.00 \\
\hline 12 & 22 & 448 & 20.4 & 2.19 & 18 & 363 & 20.2 & 2.10 & 40 & $\$ 11$ & 20.3 & 2.15 \\
\hline 13 & 25 & 582 & 23.4 & 2.97 & 21 & 448 & 21.3 & 2.14 & 46 & 1030 & 22.4 & 2.60 \\
\hline & 25 & 610 & 24.4 & 2.91 & 28 & 662 & 23.6 & 3.05 & 53 & 1272 & 24.0 & 2.99 \\
\hline
\end{tabular}

The increase in ability to repeat syllables, according to this data, is fairly uniform, with a close parallelisn between the two sexes. The greatest increase is hetween the ages of twelve and thirteen, with a slight drop between nine and ten. My results agree with those of Binct showing twenty-four syllables for 
the fourteen year group while the Binet tests use twenty-six for the fifteen year group.

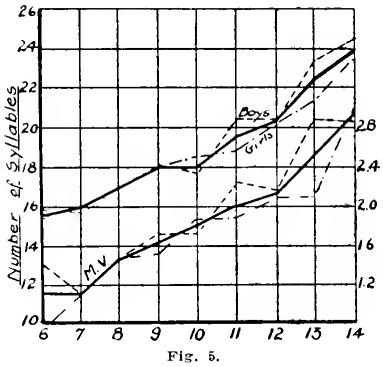

The comparative ability of the fourteen and six year group is given in table IX.

TABLE IX.

\begin{tabular}{|c|c|c|c|c|}
\hline Boy & & $\begin{array}{l}6 \text { Yrs. } \\
15.5\end{array}$ & $\begin{array}{c}14 \text { Yrs. } \\
24.4\end{array}$ & $\begin{array}{c}\% \text { Increase } \\
57\end{array}$ \\
\hline Gir & 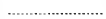 & 15.9 & 23.6 & 48 \\
\hline Both & 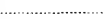 & 15.7 & 24.0 & 53 \\
\hline
\end{tabular}

Curves for variation in ability to repeat syllables, and mean variation for the different ages are given in figures 5 . 
Test IV.

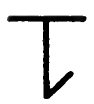

Immediately following the third test the whild is given a test involving visual and motor memory. The material used is five odd shaped figures which have been adopted from those given in Seashore's Manual. ${ }^{(19,132)}$ By referring to tigure 6 it will be noticed that these are made up of a vertical and a horizontal line, each thirteen $\mathrm{mm}$. in length, and drawn at right angles to one another. At the opposite, or unattached end of the vertical line, a third line, six and one-half $\mathrm{mm}$. in length, is drawn, at an angle of $45^{\circ}$. The variation in form of the figures is made by different combinations of these three lines. The first and last, the second and fourth, may be said to be pairs. in that they are identical but inverted. This similarity was noticed by some ehildren and hecame an aid in memorizing the figures.

The method is as follows: The child is given a piece of blank paper and shown the figures for perhaps a serond while the operator makes this explanation: "Now I'm going to let you look at these things for just a few seconds, and then when I talie them away, you draw as many as Hou cun rrmembcr. Here's the pencil." The figires are removed at the word "seconds." This places the whild in the proper attitude and shows definitely what is wanted in the briefest possible amonnt of time. I hit upon this method after several experiments in the preliminaries, during

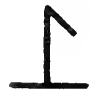
which 1 used the word "figures," I found that this suggested the arabie figmres, henee I adopted the worl "thimgs" while letting the rhild see the oh.jets themselves. Following the ahove explanaFig. 6 . tim, after a panse of about two seconds to notice by the child's expression whether or not the problem was clear, the slip on which the figures were drawn is placed on the blank paper directly in front of the child with the remark: "Now study them carefully." After an exposure of ten seconds the slip is quietly but quickly removed and the child told to draw as many as he can remember. During this process the operator must be absolutely quiet. A shight disturbance may interfere with the reaction, but in general, the child draws at once all of the figures which he remembers. I found that it was useless to wait for further results after about fifty seeonds. When the child has drawn as many figures as possible from the first exposure his paper is turned over or covered up for another trial, with the remark "Draw here next time," which indicates that the experiment is to be repeater. and also inhibits the tendency to look at the previous work. The test is given three times with the same instructions in each instance. The child is not permitted to look at his work until 
the three trials are finished and no hint should be given concerning his accuracy until the completion of the test.

In evaluating this test I allow one point for each figure correctly drawn, giving full credit for repetition of figures drawn in suceeding trials, but not for figures duplicated in the same trial. Half eredit is given if a figure is reversed, but no credit if a figure is inverted.

After a little practice the operator is able to count the number of correct figures while the child is drawing them, immediately filling in the blank. The data for each trial were kept separate, but in the following table, which gives the summary, the total for the three trials is used.

TABLE $X$.

\begin{tabular}{|c|c|c|c|c|c|c|c|c|c|c|c|c|}
\hline \multicolumn{6}{|c|}{ BOYS } & \multicolumn{3}{|c|}{ GIRLS } & \multicolumn{4}{|c|}{ BOTH } \\
\hline $\operatorname{Ag} C$ & No. & Total & Ar. & M. 1 . & No. & Total & A. & M. V. & No. & Total & Av. & 11. V \\
\hline 6 & 20 & 41.0 & 2.0 & 1.3 & 20 & 31.5 & 1.6 & .96 & 40 & 72.5 & 1.8 & 1.12 \\
\hline 7 & 23 & 64.0 & 2.8 & 1.43 & 17 & 38.5 & 2.3 & 1.19 & 40 & 192.5 & 2.6 & 1.28 \\
\hline 8 & 19 & 67.0 & 3.5 & 1.21 & 22 & 67.0 & 31 & 1.55 & 41 & 134.0 & 3.3 & 1.4 \\
\hline 9 & 27 & 125.5 & 4.6 & 1.56 & 26 & 87.5 & 3.0 & 1.40 & 53 & 213.0 & 4.0 & 1.54 \\
\hline 10 & 20 & 86.5 & 4.3 & 1.54 & 22 & 100.0 & 4.5 & 1.82 & 42 & 185.5 & 4.4 & 1.69 \\
\hline 11 & 24 & 138.0 & 5.7 & 2.36 & 25 & 123.5 & 4.9 & 1.47 & 49 & 261.5 & 5.3 & 1.84 \\
\hline 12 & 22 & 129.0 & 5.9 & 1.82 & 1s & 93.5 & 5.2 & 1.66 & 40 & 222.5 & 5.6 & 1.82 \\
\hline 13 & 25 & 171.5 & 6.8 & 1.83 & 21 & 142.0 & 6.7 & 1.71 & 46 & 313.5 & 6.8 & 1.80 \\
\hline 14 & 25 & 203.0 & 8.1 & 1.62 & 28 & 195.0 & 7.0 & 1.7 & 53 & 398.0 & 7.5 & 1.86 \\
\hline
\end{tabular}

This yroved to be one of the most interesting and valuable of the entire serien of touts. The method of drawing the figures. the motions with the pencil which often accompany the learning. and other facts which arise in individual wases. make the test of especial use in diagnosis, aside from its value as a unit in the present work. For example, a student who is a distinct motor type will trace the fignes in the air while stulying them. Mature students who are proficient in band work will draw with acematy and precision regardless of their ability in ther lins; of work. Moreover, the correlation with intelligence is very close, the curve being strikingly parallel with the summation enve shown in figure 18

The norms show a typical increase in ascending the age scale, with a emparatively small mean variation. See figure 7. This test folly meets the important requirements of an intelligence test, being uniform thronghont, and having a wide range between the rimer and lower linits, as shown in table XI.

TABLE XI.

$\begin{array}{lcccc} & & 6 \text { Yrs. } & 14 \text { Yrs. } & \% \text { Increase. } \\ \text { Boys } & \ldots \ldots \ldots \ldots \ldots & 2.0 & 8.1 & 300 \\ \text { Girls } & \ldots \ldots \ldots \ldots & 1.6 & \mathbf{7 . 0} & 338 \\ \text { Both } & \ldots \ldots \ldots \ldots \ldots \ldots & 1.8 & \mathbf{7 . 5} & 317\end{array}$




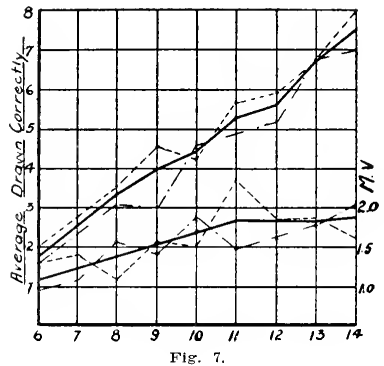

Test V.

Number of Objects Named in One Minute.

This test is atapted from the third test in Binet's twelve year series, in which the rhild is required to name as many words as he can in three minutes. $\mathrm{N}_{\mathrm{Y}}$ instructions to the child are as follows: "Nhot your eles. Now nome oeer all the things you rat thinh of : jent thing-any object." This is usually sufficient except in a minority of cases in the lower years. If

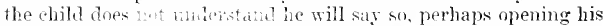
eyes, in asking for further information. In such a "ase it may be neressary to e plain what is meant by thing; ordinarily the statement "A bok is a thing" is sufficient to start the reaction. The child will shut his eves and hegin with the word book. I snap the wat b at the cound of the first word, allowing the reaction to continue for onc minute. If the key-word-book-is required, it is nut comnted in the total number of words. Credit is given for the common novns only. If the child gets started on a series of moper names it is necessary to interrupt with the expression, "No. not that kind, just common things." This necurs, however, very seldom. The most interesting ease of the kind was noticerl dinring the preliminary trials. A very precocious girl of ten years started to name the states and was well down the list before sidetracked. Occasionally, in the lower ages, the child will need additional stimulus. During longer pauses suggestive of waning attention, I break in with "Something else." which serves to renew the effort.

For purposes of diagnosis the words should be taken down, but I found it impracticable to do so except for the younger children. From the psychological standpoint this test is interesting and very significant in its bearing on mental ability. "Besides the number of words, one can note their relations; some subjects give only detached words, each of which requires an effort to recall. Others give a series of words, the furnishings of a school, various articles of clothing, etc. Some 
use only names of common objects, others cite abstract qualities or rather far-fetched words. All this gives an idea of the mentality of the subject. " $(4,50)$ A series given by a child of six may contain words which have no obvious relation; as, for example, the following: pencil, garden, doll, boat, horse, chair. On the other hand a mature child names objects in a regular series of associated words, of ten without a break. The following list was given by a boy of ten: book, school, tires, building, houst, sidewalk, street, ground, street car, trolley, iron, blacksinith shop. rigars, candy, confectionery, paper, pencil, music. music rack, piano, flute, book, magnifying glass, orange, potato, radish beet, carrot, turnip, hygiene. Rapidity of naming objects is, of course, facilitated by association, hence the older child will give a greater number of words. "Little children exlatust an itlea in naming it; they say, for example, hat, then pais in to another object without noticing that hats differ in color. in form, have various parts, have different uses and accessories. . . . Their lack of skill in the use of language, and in the analysis of ideas, is rery striking. " $(4,5,3)$

It is evident that there is a close correlation between general intelligence and ability in enumerate objects. It is also evident that this ability increases with the growth of richness in association until the age of iwelve when the maximum seems to lave heen reachet. llence for the present purpose, the results are eviluated by merely couting the number of things named the number of common nouns learing the analysis of the train at assiated work for appliratim in diagnosing the in. dividual tase.

It is helieved that the metherl here presented is superior

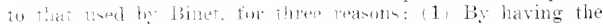
eve then the material in 10 at great extent intromeotive. The child maty lecin by naming the whipets whith he has just seen on

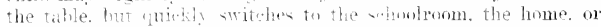

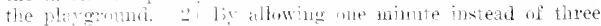
time is saver and the hild is not fatigned. The number of work in the firt tworty serond in ustaliy greater than that of the last forty and wn alvandage ran lie gained by prolonging the time. 3) The instrutions ane given in a manner which "ances the chihl to nume noms-ideas-rather than words.

In the majority of caste I was astured of a maximum of eftort on the part of the rhillren. This can be noticed by the factal expresion. which "an be arefully studied while the eyes are chosed for this exereise.

TABLE XII.

Number of things named in one minute. BuIS (aRLS

EOTII

\begin{tabular}{|c|c|c|c|c|c|c|c|c|c|c|c|c|}
\hline Agr & Nio. & Tutal & A. & M. I. & No. & Tot 31 & An. & II. $v$. & $\mathrm{N}_{n}$ & Total & An. & MI. 1 \\
\hline 6 & \pm 17 & 208 & 13.4 & 5.3 & 20 & 235 & 11.7 & 3.95 & 40 & 503 & 12.5 & 4.65 \\
\hline 7 & 23 & 327 & 14.2 & 4.2 & 17 & 2039 & 14.1 & 5.02 & 40 & Etiti & 14.2 & 4.57 \\
\hline 8 & 19 & 350 & 18.4 & 46 & 22 & 880 & 17.3 & 4.82 & 41 & 730 & 17.8 & 4.69 \\
\hline 9 & 27 & $62 \frac{1}{3}$ & 23.1 & 5.36 & 26 & 554 & 21.3 & 4.70 & 53 & $11 \% 5$ & 22.2 & 5.36 \\
\hline 10 & 20 & $45 \%$ & 22.0 & 6.05 & $2:$ & 485 & 22.0 & 6.40 & 42 & 938 & 22.3 & 6.22 \\
\hline 11 & 24 & 504 & 29.3 & 6.56 & 25 & 639 & 25,6 & 4.97 & 49 & 1343 & 27.4 & 5,82 \\
\hline 12 & 20 & 661 & 30.0 & 4.55 & 18 & $6: 8$ & $3 \pm .9$ & 6.277 & 40 & 1289 & 32.2 & 6.45 \\
\hline 13 & 25 & 775 & 31,0 & 7.25 & 21 & 606 & 290 & 9.19 & 46 & $13 S 1$ & 30.0 & 7.72 \\
\hline 14 & 25 & 789 & 21.0 & 5 & 28 & 924 & 33.0 & 6.36 & 53 & 1700 & 32.1 & 5.85 \\
\hline
\end{tabular}


The eurve indicating increase in number of things named is given in figure 8 . The increase is greatest between the ages seven and nine, ten and twelve. No gain is made from twelve to fourteen. The drop between twelve and thirteen is eaused by a lessened ability on the part of the girls, which ean perhaps be traeed to physiologieal canses. The boys outrank the girls in all ages except at twelve and fourteen.

The lower curve of figure 8 shows the fluetuation of the mean variation. This curve is strikingly similar to the curve of increase in ability (the upper), exeept that the variations are one year later. For example, at ten years the mean variation is high, while the inerease in ability over the preceding year is but slight; at eleven the mean variation drops, while the ability curve rises: at thirteen the mean variation is high. with a corresponding drop in ability ; at fourteen the eonditions are just the reverse.

The per cent. of gain of the fontteen year old ehildren over the six year old children in number of ideas named during one minute is given in table XIII.

TA.BLE XIII.

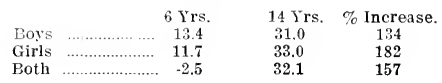

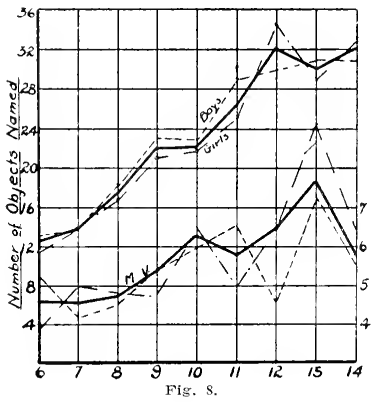

Test VI.

The sixth test is a problem involving judgment of visual proportion. The ehild is told to draw a pieture of a tree which is fifty feet high, with a man standing by it. For ages six and seven this was varied, beeause of the fact that the term fifty feet possesses but little signifieanee for younger children. In faet, it was doubted at first whether this would be a test ap- 
plicable to all ages, but subsequent trials proved it to be especially valuable. The children of six and seven years of age were told to draw "A great, big, high tree, fifty feet high with a man standing by it." "*

The height of the tree and man were measured in millimeters and the comparative height of the latter computed at once on the slide rule by means of the following simple formula: $\mathrm{H}=50 \mathrm{NH} \mathrm{T}$, where $\mathrm{H}$ represents the required height of the man, II actual height of man in millimeters, and $\mathrm{T}$ actual height of tree in millimeters. In practice 1 measure $\boldsymbol{H}$, divide by 2 , mentally, then on the slide rule divide this by $T$, properly placing the decimal.

While the childreu, with a few exceptions, had taken the regular course in drawing, the sense of proportion does not display itself, except relatively, until the later years are reached. $\Lambda$ consistent effort to draw to seale is not shown except during the years thirteen and fourteen, and then only in scattered instances. In general. the erudest drawings are acompanied by the poorest sense of proportion. We have exemplified here the development of the ability of self expression through drawing. The children of six make the "nstomary rectangular trunk with a spray of branches protuding from the upper end. The lack of co-ordination of the accessory muscles is shown by the square head and body of the man. Training in drawing displays itself in the style of tree (for example, during the holiday season the ehildren all drew Christmas trees), but there is no evidence of transfer to ability to judge proportion.

The relative height of the man with variations is given in table XIV.

TABLE XIV.

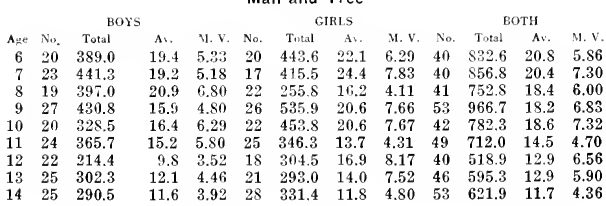

The eomparative height of the man for the different ages is indicated in the upper graph in figure 9. The irregularity is to be expected from six to nine. The ten year group shows a weakness in the sense of proportion while a marked gain is shown from ten to twelve. There is no improvement from twelve to thirteen, but a decided advance from thirteen to fourteen. The boys indicate a higher ability in this problem than the girls; furthermore the points of greatest increase for the

*All drawings made by the child are kept on the sheet of blank paper furnished him in test IV. 
boys are coincident with a backward drop for the girls, for example, ages nine, ten and twelve.

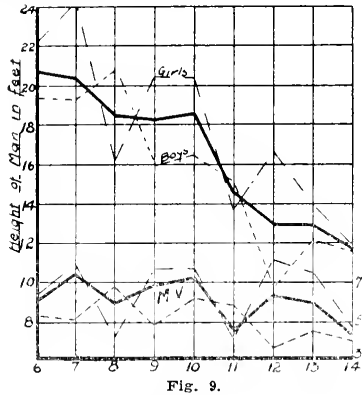

The "mrve of mean variation and that indicating relative height of the man, are strikingly similar. The two curves for wirls are virtually parallel. Likewise the curves for boys, and the curves for the entire gromp. This signifies that the groups which show greatest ability in judging the proportionate height uf the man are the least variable.

While the arre is more irregular than one would hope for, nevertheless the test has great value in diagnosis. The intelfectnal rhitd. the matnre child, never fails to grasp the significance of the test. On the other hand, young ehildren and the immature in the upper ages neglect the main point to a rreat extent. In dinical cases I have had a precocions ten rear wh ginl draw the man six feet in height; while a badly retarded wirl of fifteen drew the man twenty-two feet in height.

\section{Test VII.}

\section{problems.}

This test is in realify a gromp of seven problems, designed to test the judement. ingentaity. and inventive ability of the hille.

Problem 1.- A smonte piece of wardboard, $72 \mathrm{~mm}$. in each Jimension, is wh into fomp enal isoseles triangles along the fwo dingonals. The matorial neer in this and the two snceeding problems is a high grarie four-ply eard, black on one side, cray on the other. The ahith is restured to keep the black side 11p. The child is wiven the fom triangles and requested to put them together so that they will fook like the model (a card board of the original size and form?. The instructions are. "Put these loyether so that they will look eractly like that," spoken while plaring the pieses in front of the whild. 


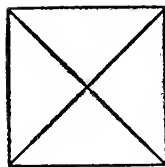

Prob. I.

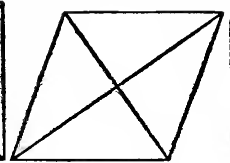

Prob. II.

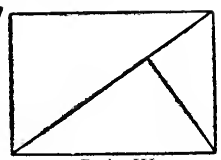

Prob. III.

In problems 1, 2 and 3 , the time required for the solution was taken with the stop watch and a record kept. It was soon found that ability was not directly proportional to the time required and, after a large number of preliminary tests, the problem was counted correct if solved within three minutes. The precocious child is apt to put the pieces together quickly, but a child who slowly and deliberately, after repeated trials, finally reaches a solution should receive full eredit.

Problem 2.-A rhombus, whose sides were each $72 \mathrm{~mm}$., angles $60^{\circ}$ and $120^{\circ}$, was cut into four equal right triangles along the two diagonals. A model of the same dimensions was used. The entire procedure was as in problem 1, allowing three minutes for a solution.

These two problems are similar in form yet present contrasting difficulties. In the first, the child immediately places two triangles together, hypotenuse against hypotenuse, forming a square. This is repeated with the other two triangles and the whole put together in the form of a rectangle. The child of low mentality usually is satisfied with this rectanglar form and is ready for the next test. The normal child, on the other hand, breaks up the form and tries another method. The procedure in problem two is to form a symmetrical figure by placing two triangles together along their longest side. As a matter of fact, the alesthetic demand for symmetry and balance asserts itself in all ages in these three tests, and must be overcome before a solution is possible. For example, the children, after picking up two triangles, will habitually put them together, thus
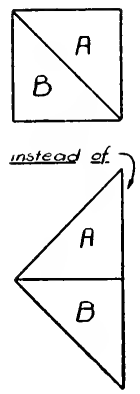
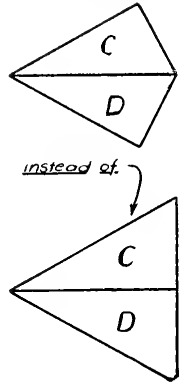
Problem $3{ }^{*}-$ A rectangle $52 \mathrm{~mm}$. $\times 80 \mathrm{~mm}$. is cut into three triangles, all similar but unequal, as indicated in figure 10. The method is the same as that nsed in the two preceding problems.

In ease of failure, we pass to the next test with the remark, "We'll let that one go for a few minutes. Here's another one which I think is easier." In no ease should the attention of the child he drawn to a lack of snecess. The effort seemed to he constant, and usually represented the maximum of the rhild's ability. In several instances, after finishing these three tesis, I have had a "hild say. "Yes, but I want to try that other one again. I believe I can get it now."

The general perults for these problems are given in the following table:

TABLE XV.

\begin{tabular}{|c|c|c|c|c|c|c|c|}
\hline \multirow[b]{3}{*}{ Age } & \multirow[b]{3}{*}{ No, Ch. } & \multicolumn{2}{|c|}{ Problem 1} & \multicolumn{2}{|c|}{ Problem 2} & \multicolumn{2}{|c|}{ Problem 3} \\
\hline & & No. & Ave. Time & No. & Ave. Time & No. & Ave. Time \\
\hline & & ('orrect & in Sec. & Correct & in Sec. & Correct & in Sec. \\
\hline 6 & 40 & S & 46 & 11 & 60 & 2 & 75 \\
\hline 7 & 40 & 9 & 63 & 14 & 81 & 7 & 60 \\
\hline S & 41 & 17 & 74 & 15 & 75 & 13 & 48 \\
\hline ! & 53 & 14 & 66 & 23 & 81 & 23 & 74 \\
\hline 10 & 42 & 20 & 66 & 33 & 60 & 23 & 69 \\
\hline 11 & 49 & 26 & 67 & $3 \pi$ & 65 & 35 & 56 \\
\hline 12 & 40 & 20 & 59 & 30 & 55 & 23 & 73 \\
\hline 13 & 46 & 28 & 72 & 36 & 70 & 37 & 70 \\
\hline 14 & 53 & 86 & 76 & 45 & 59 & 37 & 86 \\
\hline
\end{tabular}

Table XVI. qives the perentages of correct solutions of atch problem for each age.

TABLE XVI.

\begin{tabular}{cccc} 
& \multicolumn{4}{c}{ Boys } \\
Age & 1 & 2 & \\
& -5 & - & - \\
6 & 30 & 35 & 5 \\
7 & 33 & 61 & 26 \\
8 & 47 & 47 & 37 \\
5 & 30 & 41 & 56 \\
10 & 55 & 60 & 60 \\
11 & 58 & 79 & 67 \\
12 & 55 & 87 & 60 \\
13 & 76 & 84 & 84 \\
14 & 92 & 80 & 80
\end{tabular}

\begin{tabular}{rcr}
\multicolumn{3}{c}{ Girls } \\
$\%$ \\
1 & Solving \\
-5 & 2 & 3 \\
5 & 20 & 5 \\
12 & 18 & 6 \\
41 & 27 & 18 \\
35 & 46 & 31 \\
51 & 64 & 64 \\
48 & 72 & 72 \\
50 & 72 & 61 \\
57 & 76 & 76 \\
93 & 90 & 64
\end{tabular}

Both $\%$ Solving

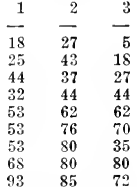

This table hears me ont in the method used in evalnating the results of these three problems. Indicated graphically in figure 11, we may infer that the length of time is more or less irrelevant. mrovided three minutes is the limit.

*Taken from Mrs. Squire's monograph (22).

Ave. $T$. is the average time of those who actually solved the problems. While somewbat irrelevant, I give this table to show that, of those who can put the puzzles together within the time limit, there is no correlation with age. In fact. we may say that the average time of those who can put the puzzles together within three minutes, inrreases with age. I suggest this explanation: The younger chlldren either solve it at once or reach their limit of ingenuity after. the first few trials, while the older children are more persistent, a larger proportion solving the puzzle, but with a longer average time. 


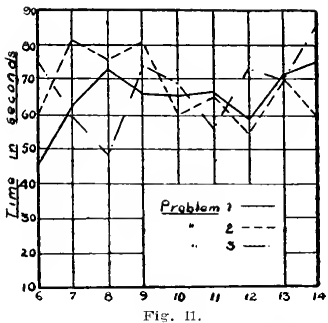

Problem 4.-This is the paper cutting test used by Binet in his 1908 series. A sheet of note book paper is twice folded double in the presence of the ehild, and the corner formed by the center of the paper is cut off, forming a diamond shaped figure in the center. The child is required to draw a picture of the paper showing the ent. The instructions are given in the following sentence: "I fold this paper over like this, then like this, then I take the scissors and cut off that corner. Now draw a picture of the paper just as it would look if we were to open it and spread it flat on the tablc." 'The eut must be drawn approximately at an angle of forty-five degrees with the edges to pass as correct. That is, a square in the centre of the paper with its sides parallel with those of the paper, is classified as a failure.

TABLE XVII.

First Test in Paper Cutting.

\begin{tabular}{|c|c|c|c|c|}
\hline & & Boys & Girls & Both \\
\hline Age & & $\%$ & $\%$ & $\%$ \\
\hline 6 & 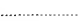 & 0 & 0 & 8 \\
\hline 7 & ........................ & 22 & 6 & 15 \\
\hline 8 & ………… & 31 & 31 & 3 \\
\hline 9 & 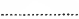 & 48 & 39 & \\
\hline 10 & $\ldots$ & 55 & 55 & 5 \\
\hline 11 & .................... & 86 & 68 & 7 \\
\hline 12 & . & 73 & $8 t$ & 7 \\
\hline 13 & ………… & 76 & 81 & 78 \\
\hline 14 & ................. & 88 & 93 & 9 \\
\hline
\end{tabular}

Problem 5.-The Binet-Simon elock problem, slightly modified, was used as the fifth in this group. The problem is to tell what time it would be by the clock if the hands were interchanged when it is (a) nine o'clock; (b) two o'clock. The instructions to the child are as follows: "Suppose it is nine o'clock by the watch and I change the hands, putting the big one where the little one is, and the little one where the big one is. What time would it be?" This was repeated for the second part using the words two o'clock. Full eredit is given if both are answered correctly, half credit if one is answered correctly. 
TABLE XVIII.

Interchanging of Hands of Clock at 9 and 2.

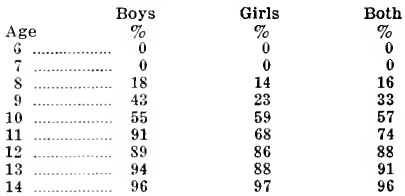

Problem 6.-.This is the reversed triangle used by Binet in the adult series. The clith is shown two equal right triangles so placed that ther will form a rectangle. The problem is to draw the two triangles as they would appear with the lower one so turned that line A-B would be against line C-D, with angle

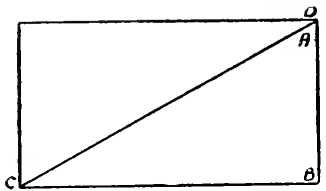

Fig. 12.

$B$ joining angle D. (Fig. 12.) The triangles are cut from a ard board rectangle $82 \mathrm{~mm}$. × $52 \mathrm{~mm}$. No letters or marks are allowed on the triangle. In giving the exercise the triangles are placed on the table before the child with the explanation: "Imagine the lower triangle to be turned around so that this edge (indicating $\mathrm{A}-\mathrm{B}$ ), is placed against this edge (indicating C.D), and this angle (B), against this angle (D). Draw a picture of the two triangles in that position." If the child does not comprehend, the instructions are repeated. Credit is allowed only when the angles are properly placed. The common error in this problem is to place the right angle in the middle of line C-D, rather than at point $D$.

TABLE XIX.

\section{Rearranging Two Triangles.}

\begin{tabular}{|c|c|c|c|}
\hline & Boys & Girls & Both \\
\hline Age & $\%$ & $\%$ & $\%$ \\
\hline 6 & 0 & 0 & 0 \\
\hline 7 & 0 & 0 & 0 \\
\hline 8 & 5 & 5 & 5 \\
\hline 9 & 0 & 0 & 0 \\
\hline 10 & 10 & 5 & 7 \\
\hline 11 & 0 & 8 & 4 \\
\hline 12 & 13 & 17 & 15 \\
\hline 13. & 32 & 5 & 20 \\
\hline 14. & 28 & 32 & 30 \\
\hline
\end{tabular}


Problem 7.-This problem is also taken from Binet, being an adult test in the 1905 series. While giving the explanation the experimenter folds a rectangular slreet of note paper, as in problem four; the cut is triangular, made in the side which presonts a single fold. The subject is not permitted to touch the paper and must not fold another sheet. Binet says of this

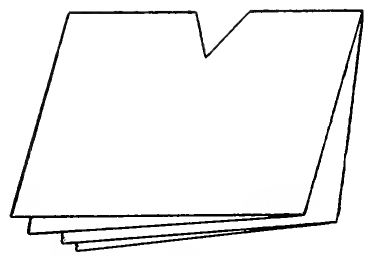

Fig. 13.

prohlem: "This test is difficult. MIost subjects simplify the solution greatly. They think that only one hole is ent, a square or a diamond, sometimes a five-pointed star, and that position is in the center of the paper." $(4,59)$ To be correct two diamonds must be drawn in line with each other on the longest diameter, one in the upper, the other in the lower laalf. If the diamonds are drawn on the shorter diameter, half eredit is allowed.

TABLE $X X$. Second Paper Cut.

\begin{tabular}{|c|c|c|c|}
\hline & Boys & Girls & Both \\
\hline Age & $\%$ & $\%$ & $\%$ \\
\hline 6 & 0 & 0 & 0 \\
\hline 7 & 0 & 0 & 0 \\
\hline 8 & 0 & 2 & \\
\hline 9 & 11 & 2 & 7 \\
\hline 10 & 10 & 18 & 14 \\
\hline 11 & 40 & 36 & 38 \\
\hline 12 & 43 & 50 & 46 \\
\hline 13 & 44 & $6 f$ & 54 \\
\hline 14 & 60 & 70 & \\
\hline
\end{tabular}

The seven problems given in test VII. are grouped together in the final scale and treated as one, hence I elassify them in table XXI. in the same manner as each of the preceding tests.

It may be mentioned that experience soon teaches an experimenter that it is useless to give all the tests in this group to each child. Only the first four are given to the six and seven year group. Problem five cannot be given to a child who is unable to tell time. Problem six is seldom given to a child who is apparently running below twelve in mentality. If a child shows signs of precocity he is given each one of the group. The rule which I observed throughout was to give the test if there was the least possibility of the child's passing it. 
TABLE XXI.

Summary of the Seven Tests in Group VII.

\begin{tabular}{|c|c|c|c|c|c|c|c|c|c|c|c|c|}
\hline \multirow[b]{2}{*}{ Age } & \multicolumn{4}{|c|}{ BOYS } & \multicolumn{4}{|c|}{ GIRLS } & \multicolumn{4}{|c|}{ вотн } \\
\hline & No. & Total & As. & M. V. & No. & Total & Av. & M. V. & No. & Total & Av. & M. $\mathrm{V}$ \\
\hline 6 & 20 & 14 & .7 & .56 & 20 & 6 & .3 & .48 & 40 & 20 & .5 & .6 \\
\hline 7 & 23 & 33 & 1.43 & .84 & 17 & 7 & .4 & .5 & 40 & 40 & 1.0 & .82 \\
\hline 8 & 19 & 35.5 & 1.87 & 1.03 & 22 & 30.5 & 1.4 & 1.1 & 41 & 66 & 1.61 & 1.08 \\
\hline 9 & 27 & 6 & 2.28 & 1.18 & 26 & 45 & 1.8 & 1.2 & 53 & 107 & 2.0 & 1.21 \\
\hline 10 & 20 & & 3.05 & .92 & 22 & 6 & 3.14 & 1.10 & 42 & 130 & 0 & .97 \\
\hline & 24 & & 3.94 & 1.31 & 25 & & 3. & & & & 2 & 1.09 \\
\hline 2 & 22 & & 4.6 & & 18 & & & & & & & .89 \\
\hline & 25 & 122.5 & 4.90 & 1.00 & 21 & & 4. & .7 & & & 4.72 & 1.00 \\
\hline 14 & 25 & 131.0 & $5.2 !$ & 1.17 & 28 & 150.5 & 5.4 & .87 & 53 & 218.5 & 5.31 & .87 \\
\hline
\end{tabular}

See lower enrve Fig. 14 for the norm.

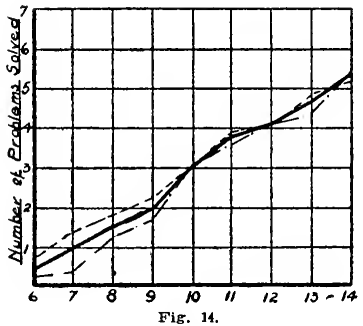

Test VIII.

\section{Definitions.}

It is generally agreed that ability to express ideas verbally is a good criterion of intelligence. In the search for a test which conld be used throughont the age series and at the same time parallel the genetic development of the child, no better test could be found than a series of definitions. The words selected fall into three groups, as follows: (1) Terms used in the every day life of the ehild, fork, horse and automobile; (2) Terms which are not so easily elassified and which require a higher type of definition than is usually given in the first group, poet and tree; (3) Abstract terms, kinduess, sweetness, charity and justice. A tenth was added nnder this heading. namely, the difference between a worm and a suake.

The test is given with the following instructions: "I am going to ask you several questions. Answer them the very best you can. First, what is a fork?"

The answers for the present purpose, are easily classified in three groups:

1. Simple repetition or silence. The common response for a six-year-old is "Why, a fork is a fork." "A horse is a horse." Children of this type use the same response for fork, horse, 
automobilc and tree and, as one would expect, make no response to the other questions, except the last "What is the difference betuen a worm and a snake?", the answer, "A snake's bigger,"

2. Definitions in terms of use.-A few typical examples: A fork is a thing to eat with. A horse is to ride on, or to pull carriages. An automobile is to ride in or earry groceries in. A tree is to get fruit off of. As Binet says, "All these answers are learly infantile, not only in their incorrect form, but also in their conciseness, and finally in the state of mind which they reveal; scarcely any children of seven years are exelusively utilitarian in their definitions.' $(4,28)$

3. Definitions in terms superior to use.-When an attempt is made to give a more elaborate definition the answers at once become much more diversified. The first step is to give the class, next the differentia. The type of answer is in large measure dependent upon the degree of the child's familiarity with the object being defined. The lowest class in this type is that in which the genus is given followed by the use. The real value of the definition depends, of course, upon the number of differentia given, and the classification. In this group horse is defined as, an animal; a beast of burden; a domestic animal usert as a betst of burden.

Method of Evaluating.-At first glance the problem of evaluating this series of definitions, so that it may be used in a point system, may seem especially difficult. But the scale which was adopted permits an accurate evaluation after a little practice. It is. brietly, this: For each definition, allow one point if in terms of use only. If the proper class is given allow one point. For each differentium allow one point. With the one restriction-no definition shall receive more than three points. In the tenth, the difference between $a$ worm and a snake, allow one-half point for each valid difference.

1. Fork.-To eat with, seore 1. Utensil used to eat with, seore 2. A table utensil used in eating, seore 3.

2. Horse.-To ride, score 1. Animal to ride on, score 2. Domestic animal, score 2. Four-legged animal, seore 1. Domestic trimat used for hauling wagons, score 3.

3. Automobile.-To ride in, score 1. A vehicle, score 1. A vehicle to ride in, score 2. A four-wheeled vehiele, score 1. t thing run by machinery, score 1. A wagon run by an engine, or a solf-propelled vehicle, seore 3 .

4. l'oet-Man that writes potry, score 1. (1n general tautological definitions do not receive eredit. The above, however. involves a higher meaning than to say "A poet is a poet.") Man who writs verses, seore 2. Man who writes stories that hinme, seore 3. Man that writes beatiful thoughts in verse form, score 3 .

5. Tree.-A thing to climb, score 1. Used for lumber, s.ore 1. To get fruit off of, seore 1. A plant, score 1. The largest of all plants, score 2. A big piece of wood growing in the ground, score 2. A large plant, with big trunk and branches, used for wood, score 3.

6. Kindurss.-To be kind, no eredit. Being nice, score 1. 
Helping others, score 2. To be polite, unselfish and helpful to others, serere 3.

7. Surtintss-Tho be swect, no eredit. Something that tustes like sugar, seore 2. A taste, score 1. Lite hindness, score 1. There are two kinds; something that tastes like sugar and when popir look sweet and are nice to one another, seore 3 . (Note-Perhaps kindness and sweetness should have been reversed. As it is, the idea of sweetness being like kindness, is given oftener than was anticipated.)

8. Charity.-Helping others, score 2. Giving help to the poor, sore 3 . (When this word was defined at all the answers were similar to those given. In the main. the concept was eonwrete rather than abstract.)

9. Justice.-To be just, no credit. To do right, seore 2. To do unto others as you would have them do to you, seore 3 . If u person is in jail and gets what's coming to him, that's justice, seore 2.

10. Difference between a worm and a snake.-One-half point for each difference. Size, form, teeth, skin, head, motion, homes, feet, color, are typical differences mentioned.

In evaluating the above definitions one must not be dereved by a high sounding phrase. but must measure the ideas "ontained in the phrase. For example, rhithen oceasionally respond to, "What is a fork?" with, "A fork is an instrument usfol to comcul food to the mouth." This does not necessarily. indicate a higher degree of intelligence; it is more likely a result of training.

TABLE $\times X \| 1$.

Summary of Points Made in Definition Test.

\begin{tabular}{|c|c|c|c|c|c|c|}
\hline \multirow[b]{2}{*}{ Age } & \multicolumn{2}{|c|}{ Boy } & \multicolumn{2}{|c|}{ Girls } & \multicolumn{2}{|c|}{ Both } \\
\hline & $A v$. & M. V. & Av. & MI. $V$ & Av. & M. $\mathrm{V}^{+}$ \\
\hline 6 & 3. & 1.75 & 3.4 & 1.8 & 3.20 & 1.86 \\
\hline 7 & 4.4 & $1.4 \mathrm{~S}$ & 4.15 & 1.36 & 4.29 & 1.45 \\
\hline 8 & 6.3 & 1.76 & 4.95 & 1.05 & $5.5 \mathrm{~s}$ & 1.49 \\
\hline 9 & 7.4 & 1.50 & 6.13 & 1.66 & 6.75 & 1.64 \\
\hline 10 & .. 1 & 1.90 & 8.32 & 2.58 & 7.70 & 2.52 \\
\hline 11 & 11.8 & 2.17 & 10.62 & 1.80 & 11.17 & 2.02 \\
\hline 12 & 13.25 & 2.98 & 11.36 & 2.14 & 12.40 & 2.80 \\
\hline 13 & 14.12 & 2.57 & 13.48 & 2.52 & 13.82 & 2.56 \\
\hline $14=$ & 15.3 & 3.86 & 15.40 & 2.91 & 15.35 & 3.16 \\
\hline
\end{tabular}

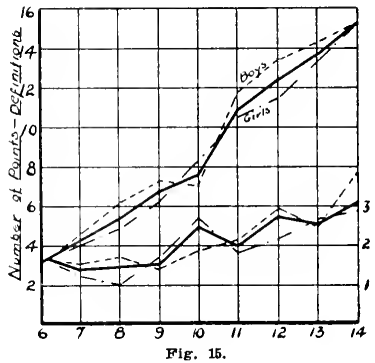


Test IX.

\section{Sorting Cards.}

For this test a set of fifty eards is employed utilizing the rather complex function of discrimination of form and color. The cards used are of highest grade duplex calling card stock. in size the same as an ordinary plaving eard, $63 \times 89 \mathrm{~mm}$. Spots are arranged as shown in figure 16, forming five sets of ten cards each. Colors used are blue, green and red; forms are circle, $101_{2}, \mathrm{~mm}$. in diameter, a square $9 \mathrm{~mm}$. each side, and an equilateral triangle each of whose sides is $14 \mathrm{~mm}$. (Area of spots practically equal.) The cards are sized with collodion as a protection to the colors.

In all sets the colors are retained in the same order, namely, blue at the top, green in the middle, and red at the bottom.*
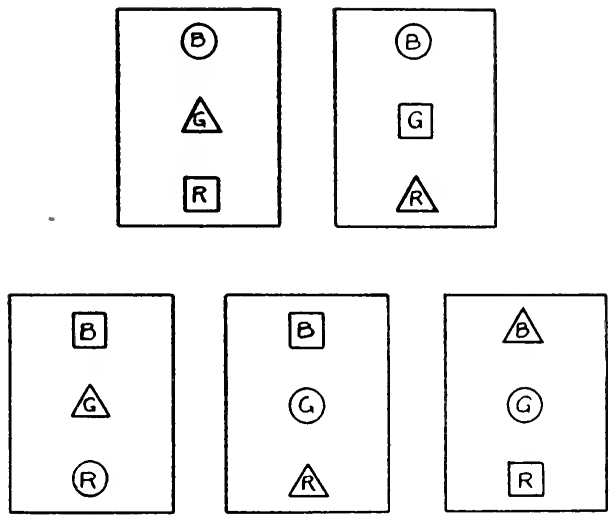

Fig. 16.

After carefully shuffing the cards they are shown to the student with the explanation, "Now I want you to sort these cards for me. I'll show you the different kinds there are. This one, and this one, etc. Now you are to sort them over, putting ihe ones that are just alike in the same piles. Do you see how they • are all difjerent?" In the meantime the experimenter may be shuffling the cards allowing sufficient time-about one minutefor the ehild to discover the fundamental differences in the five sets. Then gathering up the five sample cards, place them

*Sets may be secured by communicating with the author. 
at the bottom of the deck and hand all to the child with the remark: "If you find a card and have no place to put it, start a neu pile. Just as quickly as you can now, but don't make any mistakes." A record is kept of the time in minutes and seeonds, with the number of errors.

In this test eare should be taken to see that the child understands the problem thoronghly. The differences in the cards should not be explained, but, in the cases of slower children, a little longer time may be allowed in looking at the cards at first. The common type of error is to place the two sets which have circles at the top in the same pile. Cards must not be inverted.

As a means of quickly detecting mistakes in piling, the set number-1, 2, 3, 4, or 5-is placed on the back in the upper left hand corner. An error is counted each time a new number appears in the conrse of running them through. That is. suppose set 4 ehecks as follows: $4-4-4-3-4-2-2-2--4-2$. We have here five errors-one when eard 3 was placed on eard 4 , one when card 4 was placed on eard 3 , one when card 2 was placed on card 4 , ete. The theory being that each time a wrong eard is placed on a pile the pile takes the individuality of the new eard, and adding any other card than the new will constitute an error.

Count is also taken of the number of piles. Usually there are more errors than extra piles. but if this is not the ease, each extra pile above the number of errors constitutes an error.

In tabulating results I was unable to find any particular degree of correlation between accuracy and speed, except in in. dividual cases. To analyze this factor would necessitate taking cach age as a group and evaluating the correlation. There are indications of such a correlation, especially in the older groups.

In the following table seconds have been changed to fraetions of a minute for convenience.

TABLE XXIII.

Card Sorting Test.

\begin{tabular}{rrrrrr} 
& \multicolumn{2}{c}{ Girls } & \multicolumn{2}{c}{ Both } \\
Age Av. & Moys. V. & Av. & M. V. & Av. & M.V. \\
$6-6.27$ & 1.23 & 6.79 & 1.33 & 6.53 & 1.28 \\
$7-5.73$ & .73 & 4.88 & .90 & 5.37 & .84 \\
$8-5.29$ & .91 & 4.50 & .70 & 4.86 & .86 \\
$9-4.45$ & .62 & 4.54 & .95 & 4.50 & .77 \\
$10-4.36$ & .70 & 3.76 & .78 & 4.05 & .79 \\
$11-3.62$ & .73 & 3.48 & .52 & 3.56 & .65 \\
$12-3.79$ & .69 & 3.03 & .43 & 3.45 & .64 \\
$13-3.45$ & .82 & 2.84 & .47 & 3.17 & .73 \\
$14-3.13$ & .67 & 3.09 & .49 & 3.10 & .61
\end{tabular}

In this test the girls are slower than the boys except at the ages six, nine and fourteen. The girls' greatest variation comes at the point where they make their greatest gain-year seven. The greatest increase in speed is prior to year eleven. But little increase $(3.56 \mathrm{~min}$. to $3.10 \mathrm{~min}$.) is apparent from eleven to twelve. (See Fig. 17, upper curve.) 


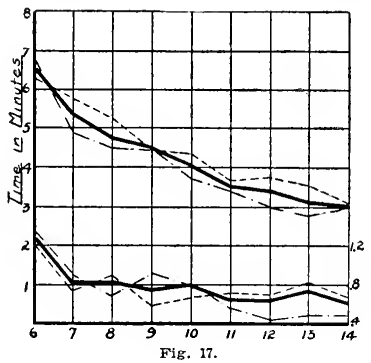

TABLE XXIV.

Average Number of Errors Made in Sorting Cards.

\begin{tabular}{|c|c|c|c|c|c|c|c|c|c|}
\hline . & 6 & 7 & 8 & 9 & 10 & 11 & 12 & 13 & 14 \\
\hline ys $\ldots$ & 6.2 & 4.4 & 5.7 & 5.0 & 5.1 & 6.0 & 4.8 & 5.2 & 4.8 \\
\hline & 6.1 & 4.4 & 5.4 & 5.3 & 4.8 & 4.9 & 5.0 & 5.0 & 4.1 \\
\hline & 6.1 & 4.4 & 5.6 & 5.2 & 4.9 & 5.5 & 4.9 & 5.1 & 4.4 \\
\hline
\end{tabular}

In practice, and in evaluating the number of points for this test (see next paragraph). I add to the actual time, an additionål time of three seconds for each error.

\section{Evaluation of Points for the Graduated Scale.}

The assigning of weight to each of the several tests is necessarily an arbitrary matter. The ideal would be to give equal weight to the various mental processes if they could be labeled and tested. But that being impossible, effort was made to distribute the weights to the varions tests in a manner which would facilitate, rather than hinder the task of evaluating the material, while at the same time distributing the points so that the increase from year to year would be as large as possible.

Test 1.-Allow one point for each object enumerated.

Test II.-Allow one point for each digit.

Trst III.-Divide number of syllables by 4 . (This gives auditory memory for syllables the same weight as auditory memory for digits.) (See table XXV.)

Test $1 \mathrm{~V}$.- Allow two points for each figure correctly drawn.

Test $V$.-Divide total number words given by 3 .

Test VI.-Numher of points allowed is obtained by dividing 100 by the height of the man.

Test VII.-Multiply points made in the seven problems by 3.

Trst VIII.-Allow one point for each score as indicated in the description of this test.

Test $I X$.-Divide 30 by the time taken in sorting the cards recorded in minutes. 
In the summation of points boys are higher than girls except at year ten and the curves will probably cross soon after year fourteen. (See tables XXV. and XXVI.)

TABLE XXV.

Summation of Points for Boys.

\begin{tabular}{|c|c|c|c|c|c|c|c|c|c|}
\hline Test & 6 & 7 & 8 & 9 & 10 & 11 & 12 & 13 & 14 \\
\hline 1 & 3.3 & 4.2 & 4.3 & 5.0 & 5.0 & 5.8 & 5.6 & 5.9 & 6.1 \\
\hline 2 & 4.3 & 5.0 & 5.4 & 5.7 & 5.7 & 5.8 & 6.0 & 6.1 & 6.4 \\
\hline 3 & 3.9 & 4.1 & 4.3 & 4.6 & 4.4 & 5.6 & 5.6 & 5.9 & 6.1 \\
\hline 4 & 4.0 & 5.6 & 7.0 & 9.2 & 8.6 & 11.4 & 11.8 & 13.6 & 16.2 \\
\hline 5 & 4.5 & 4.7 & 6.1 & 7.7 & 7.5 & 9.8 & 10.0 & 10.3 & 10.3 \\
\hline 6 & 5.2 & 5.2 & 4.8 & 6.3 & 6.1 & 6.6 & 10.2 & 8.3 & 8.7 \\
\hline 7 & 2.1 & 4.3 & 5.6 & 6.8 & 9.2 & 11.8 & 12.3 & 14.7 & 15.7 \\
\hline 8 & 3.0 & 4.4 & 6.3 & 7.4 & 7.1 & 11.8 & 13.3 & 14.1 & 15.3 \\
\hline 9 & 4.6 & 5.0 & 5.4 & 6.4 & 6.4 & 7.8 & 7.4 & 8.1 & 8.9 \\
\hline & & 42.5 & 49.2 & 59.0 & 60.0 & 76.4 & 82.1 & 87.0 & 93 \\
\hline
\end{tabular}

TABLE XXVI.

Summation of Points for Girls.

\begin{tabular}{|c|c|c|c|c|c|c|c|c|c|}
\hline Test & 6 & 7 & 8 & 9 & 10 & 11 & 12 & 13 & 14 \\
\hline 1 & 3.3 & 4.2 & 4.4 & 4.7 & 5.0 & 5.6 & 5.9 & 6.3 & 6.6 \\
\hline 2 & 4.5 & 4.9 & 5.6 & 5.6 & 5.5 & 5.8 & 6.0 & 6.0 & 6.3 \\
\hline 3 & 4.0 & 4.0 & 4.3 & 4.5 & 4.6 & 4.7 & 5.5 & 5.3 & 5.9 \\
\hline 4 & 3.2 & 4.6 & 6.2 & 6.0 & 9.0 & 9.8 & 10.4 & 13.4 & 14.0 \\
\hline 5 & 3.9 & 4.7 & 5.8 & 7.1 & 7.3 & 8.5 & 11.6 & 9.6 & 11.0 \\
\hline 6 & 4.5 & 4.1 & 6.2 & 4.9 & 4.9 & 7.3 & 5.9 & 7.2 & 8.5 \\
\hline 7 & .9 & 1.2 & 4.2 & 5.4 & 9.4 & 11.1 & 12.6 & 13.5 & 16.2 \\
\hline 8 & 3.4 & 4.2 & 5.0 & 6.1 & 8.3 & 10.6 & 11.4 & 13.5 & 15.4 \\
\hline 9 & 4.2 & 5.9 & 6.3 & 6.3 & 7.5 & 8.0 & 9.2 & 9.7 & 9.1 \\
\hline & 1.9 & 37.7 & 48.0 & 50.6 & 61.5 & 71.5 & 78.5 & 84.4 & 93.0 \\
\hline
\end{tabular}

For all purposes of elassification, lowever, the two are combined giving the following:

TABLE XXVII.

Summation of Points (See Fig 18.)

\begin{tabular}{|c|c|c|c|c|c|c|c|c|c|}
\hline Test & 6 & 7 & 8 & 9 & 10 & 11 & 12 & 13 & 14 \\
\hline 1 & 3.3 & 4.2 & 4.3 & 4.9 & 5.0 & 5.7 & 5.7 & 6.1 & 6.4 \\
\hline 2 & 4.4 & 4.9 & 5.5 & 5.7 & 5.6 & 5.8 & 6.0 & 6.1 & 6.4 \\
\hline 3 & 3.9 & 4.0 & 4.3 & 4.5 & 4.5 & 4.7 & 5.1 & 5.6 & 6.0 \\
\hline 4 & 3.6 & 5.2 & 6.6 & 8.0 & 8.8 & 10.6 & 11.2 & 13.6 & 15.0 \\
\hline 5 & 4.2 & 4.7 & 5.9 & 7.4 & 7.4 & 9.1 & 10.7 & 10.0 & 10.7 \\
\hline 6 & 4.8 & 4.7 & 5.5 & 5.5 & 5.4 & 6.9 & 7.8 & 7.8 & 8.6 \\
\hline 7 & 1.5 & 3.0 & 4.8 & 6.0 & 9.3 & 11.4 & 12.4 & 14.1 & 15.9 \\
\hline 8 & 3.2 & 4.3 & 5.6 & 6.8 & 7.7 & 11.2 & 12.4 & 13.8 & 15.4 \\
\hline 9 & 4.4 & 5.4 & 6.8 & 6.3 & 7.0 & 7.9 & 8.1 & 8.8 & \\
\hline & & 40.0 & 48.8 & 5.1 & 0.6 & 73.3 & 79.4 & 35.9 & \\
\hline
\end{tabular}


A Graduated Scale for Determining Mental Age

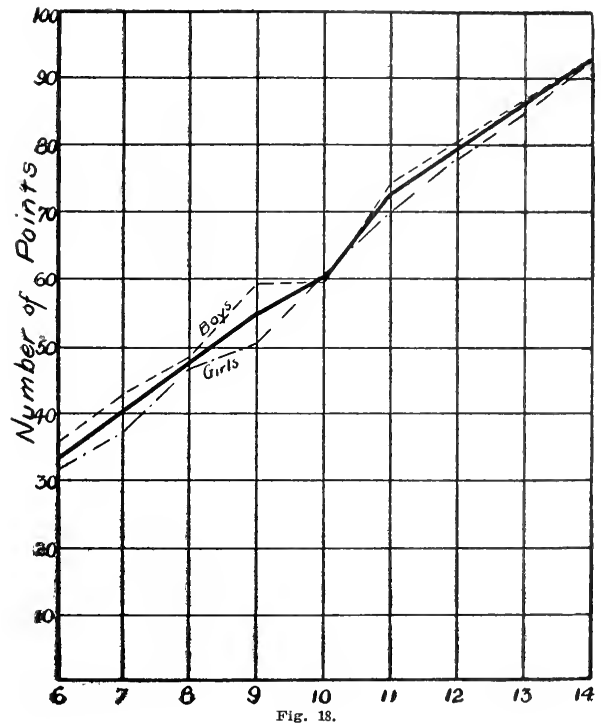


By use of interpolation the following table bas been constructed from the norms given above and serves the purpose of quickly estimating the ages to a tenth of a year.

Table XXVIII.

\begin{tabular}{|c|c|c|c|c|c|c|c|}
\hline $\begin{array}{l}\text { No. } \\
\text { Points }\end{array}$ & $\begin{array}{l}\text { Ment. } \\
\text { Age }\end{array}$ & $\begin{array}{l}\text { No. } \\
\text { Points }\end{array}$ & $\begin{array}{l}\text { Ment. } \\
\text { Age }\end{array}$ & $\begin{array}{c}\text { No. } \\
\text { Points }\end{array}$ & $\begin{array}{c}\text { Ment. } \\
\text { Age }\end{array}$ & $\begin{array}{c}\text { No. } \\
\text { Points }\end{array}$ & $\begin{array}{l}\text { Ment } \\
\text { Age }\end{array}$ \\
\hline 33.3 & 6.0 & 48.4 & 8.0 & 60.6 & 10.0 & 79.4 & 12.0 \\
\hline 34.0 & 6.1 & 49.1 & 8.1 & 61.9 & 10.1 & 80.1 & 12.1 \\
\hline 34.7 & f.2 & 49.7 & 8.2 & 63.1 & 10.2 & 80.7 & 12.2 \\
\hline 35.4 & 6.3 & 50.4 & 8.3 & 64.4 & 10.3 & 81.4 & 12.3 \\
\hline 36.1 & 6.4 & 51.1 & 8.4 & 65.7 & 10.4 & 82.0 & 12.4 \\
\hline 36.9 & 6.5 & 51.8 & 8.5 & 67.0 & 10.5 & 82.7 & 12.5 \\
\hline 37.6 & 6.6 & 52.4 & 8.6 & 68.2 & 10.6 & 83.3 & 12.6 \\
\hline 38.3 & 6.7 & 53.1 & 8.7 & 69.5 & 10.7 & 84.0 & 12.7 \\
\hline 39.0 & 6.8 & 53.8 & 8.8 & 70.8 & 10.8 & 84.6 & 12.8 \\
\hline 39.7 & 6.9 & 54.4 & 8.9 & 72.0 & 10.9 & 85.3 & 12.9 \\
\hline 40.4 & 7.0 & 55.1 & 9.0 & 73.3 & 11.0 & 85.9 & 13.0 \\
\hline 41.2 & 7.1 & 55.7 & 9.1 & 73.9 & 11.1 & 86.7 & 13.1 \\
\hline 42.0 & 7.2 & 56.2 & 9.2 & 74.5 & 11.2 & 87.4 & 13.2 \\
\hline 42.8 & 7.3 & 56.8 & 9.3 & 75.1 & 11.3 & 88.2 & 13.3 \\
\hline 43.6 & 7.4 & 57.3 & 9.4 & 75.7 & 11.4 & 88.9 & 13.4 \\
\hline 44.4 & 7.5 & 57.9 & 9.5 & 76.4 & 11.5 & 89.7 & 13.5 \\
\hline 45.2 & 7.6 & 58.4 & 9.6 & 77.0 & 11.6 & 90.4 & 13.6 \\
\hline 46.0 & 7.7 & 59.0 & 9.7 & 77.6 & 11.7 & 91.2 & 13.7 \\
\hline 46.8 & 7.8 & 59.5 & 9.8 & 78.2 & 11.8 & 91.9 & 13.8 \\
\hline 47.6 & 7.9 & 60.1 & 9.9 & 78.8 & 11.9 & 92.7 & 13.9 \\
\hline
\end{tabular}

In illustration of the use of the seale I shall add a few artial cases, selected at random from among those which were given for special reasons.

(1) R. W.. a girl, age 10 years, 1 month, seven days; $5 \mathrm{~A}$ grade. Points made for each test are, respectively, 5.7, 5.5, $11,8.6,7.1,15,10,8.1$, a total of 77.3 . Referring to table XXVII., the mental age is foum to be 11.65 years, showing an aceeleration of 1.7 years.

(2) J. B., a boy age 13 years, 2 months. 17 days: $7 \mathrm{~A}$ grade. Points made. 5, 5, 5, 23, 8.3, 4.2, 15, 12, 9.2, total 86.7. Mental age 13.1, which is identical with the chronological age.

(3) R. C.. a girl, age 11 rears, 4 months, 16 days; $3 \mathrm{~B}$ grade. Points made $3,6,5,4,7.6,7,1.5,9,4.8$, total 47.9 . Mental age, 7.9 , which is 3.4 vears helow her chronological age.

(4) C. G., a boy, age 10 vears, 1 month: $4 \mathrm{~A}$ grade. Points mare, $5,7,6,17,6.6,8.7,18,11,7.5$, a total of 86.8. Mental age 13.1. which is 3 years in advance of his chronolngical age.

The list could be extended indefinitely from the data at hand, but no attempt has been made to summarize the work with these special cases, hence I submit merely the above in illustration of the use of the seale.

\section{Conclusion.}

After using the scale in testing hetween five and six hundred whildren I have berome firmly convineed of its applicability as an instrument for " first aid" purposes. Indeed, its results are sufficient to rassify satisfactorily the majority of eases. Throughont the work. I repeatedly compared notes with the 
teacher and principal, and practically without exception, found that my estimate of the child corresponded with that of the instructor. At each school which I visited I was requested to examine special cases, with the result that the scale was thoroughly tried out. When examining children at the request of the teacher or principal I made it a rule to take the case as an "monnown." With very few exceptions my findings were corrohorated by the facts as shown by class standing and the estimate of the tearher. In many cases I have pointed out individual peculiarities which had passed umnoticed, but which were at once recognized when the teacher's attention was directed toward them. A glaring example came to light one day while I was testing children for special promotion. A boy of twelve in the sixth grade had been recommended as a candidate but, owing to his retiring disposition, his teachers were not convinced that he would be able to earry the advanced work. I found that he was mentally about four years in advance of his ageentirely beyond the range of $\mathrm{my}$ seale-and capable of carrying high school work. Even his mother was forced to admit that. even though $\mathrm{L}$ - was not ronsidered precocious, she always appealed to him as a court of last resort, when special information was wanted. As a result of my findings he was advanced one rrarle and placed in the special preparatory school.

This confidence in the scale prompts me to make the statement that it can be used by teachers and supervisors with gratifring results. With its applieation one can ascertain more in thirty minutes concerning the actual mental condition of the child than is ordinarily possible from two years of regular school work. Moreover its compactness and simplicity of operation commend it especially to teachers who lack a eomplete training in experimental pedarogr.

There is no question but that such a measuring instrument may he used greatly to increase the efficiency of any school system. There should he several scales available but all of a type which wonld eommend their use to the rank and file of the teaching profession. Only by a conscientious effort in classification will the schools of America be able to reach the standard which the public has a right to demand of them-the standard which sives each individual child the most efficient edueation of which he is rapable.

\section{Bibliography.*}

1. Bell, .T. ('- "Rerent Literature on the Binet Tests." .Jonr. of Ed. Psych.. 3:1912, 101-110.

2. Berry C. S.- "A Comparison of the Binet Tests of 1908 and 1911." .Jour. of Psych., 3:1912, 444-451.

3. Binet. A.- "I'etude experimentelle de Intelligence." Paris, 1902.

1. Pinet, A. and Simon. Th.- "A Method of Measuring the

*No attempt is here made to compile a complete bibliography. This has been ably done by Samuel C. Kohs in recent numbers of the Journal of Educational Psychology, and is now available in book form. ${ }^{14}$ 
Development of the Intelligence of Young Children." Trans. Clara llarrison Towne, Lincoln, Ill.

5. Bonsor, F. G.- "The Reasoning Ability of Children." ('olumbia Teachers' Monographs. No. 37, 1910.

6. Brown, W.- "The Essentials of Mental Measurement." London. 1911.

7. Ehbinghaus, H.- "Grundzuge der Psyehologie." Veit and Co., Leipzig. 1905.

8. — "Ueber eine nene Methods zur Prufung geistiger Fahigkeiten in ihrer Anwendung bei Schulkindern." Zeits. F. Psychologie. 13:1897.

9. Fechner, G. T.--"Elemente der Psychophysik." Leipzig. 1889. 2 vols.

10. Franz. S. I.- "Handbook of Mental Examination Methods." .Jour. of Nerv. and Ment. Dis. N. Y. 1912.

11. Godilard, H. H.- "The Binet-Simon Measuring Seale for lntelligence." Tr. Sich. 8:1911, 56-62.

12. __ - "Standard Methods for Giving the Binet Tests." Tr. Seh., $10: 1913,23-30$.

13. Huey, E. B.-“The Binet Scale for Measuring Intelligence and Retardation." .Jour. Ed. Psych. $1: 1910,435-444$.

14. Kohs. S. C.- "The Binet-kimon Measuring Scale for Intelligence." An annotated bibliography. Jour. Ed. Pysch. $5: 1914,215-224,279-290,335-346$. Book published by Warwick and York.

15. Kuhlman, F.-"A Revision of the Binet-Simon System for Measuring the Intelligenee of Children." Mon. Supp. Jour, of Psycho-Asthenics.

16. Nemmann.- "Intelligenzprufungen an Kindern der Tolkschule." Die Exp. Padgogik, 1:1905.

17. Muller, G. E.-_"Die Gesichtpunkte und die Tatsachen der psychophysichen Methodik." Weisbaden, J. F. Bergman, 1914.

18. Schwegler. R. A.- "A Teaeher's Mannal for the use of the Binet-Simon Scale of Intelligence." Univ. of Kan. Sch. of Ed., 1914.

19. Seashore, ('. E-CElementary Experiments in Psyehology." Henry Holt and Co., N. Y. 1911.

20. Simpson, B. R.- "Correlation of Mental Abilities." Columbia Contributions to Edueation, No. 53, 1912.

21. Spearman, C.- "General Intelligenee, Objectively Determined and Measured." Am. Jour. of Psych. 15:1904, 201.

22. Squire, Carrie R.- "Graded Mental Tests." Jour. Ed. Psych. $3: 1912,363-380,430-443,493-506$.

23. Stem, W.-"'The Psychologieal Methods of Testing Intelligence." Ed. Psych. Mono. No. 13, 1914.

24. Terman, L. M.- "The Measurement of Intelligence." Houghton Mifflin Co., Boston, 1916.

25. Thorndike, E. L.- "Theory of Mental and Social Measurements." Science Press, N. Y. 1904.

26. — "Edueational Psychology." Teachers Coll. Columbia ITniversity, 1910. 
27. Wallin, J. E. W.- "A Critique of the Binet-Simon Tests.' Ed. Psych. Monographs, No. 7, 1912.

28. Whipple, G. M.-."Manual of Mental and Physical Tests.' Part One. 1910. Warwick and York, Baltimore. 1915 .

29. _ _ _ _ _ _ _ Pame, Part Two, Complex Processes.

30. Wiersma, E.-“Die Ebbinghaus'sche Combinationsmethods." Zeit fur Psychologie, 30:1902, 196-222.

31. Wissler, Clark-" The Correlation of Mental and Physical Tests." Psych. Rev. Mono. Supp. 3:1901, No. 16.

32. Wundt, W.- "Grundzuge der Physiologische Psychologie." Leipzig, 1902.

33. Yerkes, R. M., and Anderson, H. M.- "The Importance of Social Status as Indicated by the Results of the Point-scale Method of Measuring Mental Capacity." Jour. of Ed. Psych. $6: 1915$, 137-156.

34. Yerkes, R. M., and Bridges, J. W.- "The Point-scale: A Method of Measuring Mental Capacity.' Boston Medical and Physical Journal, 171:1914, 857-865. Book published by Warwick and York. 


